DAMPAK SENAM HAMIL TERHADAP ROBEKAN PERINEUM Available online at: http://e-journal.unair.ac.id/index.php/IMHSJ PADA PERSALINAN NORMAL

\title{
PREGNANCY EXERCISE IMPACT TO PERINEAL TEAR IN NORMAL LABOR
}

\section{Ayunda Ardiana ${ }^{1}$,Budi Utomo ${ }^{2}$, K. Kasiati ${ }^{3}$, Bambang Purwanto $^{4}$}

1. Program Studi Kebidanan, Fakultas Kedokteran Universitas Airlangga, Surabaya, Indonesia

2. Departemen IKM-KP, Fakultas Kedokteran Universitas Airlangga, Surabaya, Indonesia

3. Jurusan Kebidanan, Poltekkes Kemenkes Surabaya, Surabaya, Indonesia

4. Departemen Ilmu Faal, Fakultas Kedokteran Universitas Airlangga, Surabaya, Indonesia.

Alamat korespondensi:

Perumdos ITS, Surabaya, 60111, Indonesia

Email : yundaardiana@gmail.com

\begin{abstract}
Abstrak
Latar Belakang: Robekan perineum adalah robeknya daerah otot - otot dasar panggul. Berdasarkan kajian Pustaka dan penelitian terdahulu, robekan perineum sering terjadi pada persalinan khususnya primigravida. Senam hamil merupakan kegiatan aktifitas fisik yang dilakukan ibu hamil. Penelitian ini bertujuan untuk mengetahui hubungan antara senam hamil dengan robekan perineum pada persalinan normal di Klinik Pratama Anugrah Surabaya._Metode: Penelitian ini menggunakan metode analitik observasional dengan pendekatan waktu retrospektif. Jumlah sampel 34 kelompok kasus (robekan perineum) dan 34 kelompok kontrol (tidak robekan perineum) pada persalinan normal dengan teknik pengambilan sampel yaitu purposive sampling. Instrumen yang digunakan adalah rekam medis, wawancara tertulis, kamera dan checklist. Analisis data menggunanakan uji statistik chi square dengan tingkat kemaknaan 0,05. Hasil: Hasil penelitian menunjukan bahwa masih banyak ibu yang tidak melakukan senam hamil selama kehamilannya sebanyak $43(63,2 \%)$. Ibu yang tidak melakukan senam hamil lebih banyak mengalami robekan perineum sebanyak $27(79,4 \%)$, sedangkan ibu yang melakukan senam hamil lebih banyak tidak mengalami robekan perineum sebanyak 18 (53\%). Hasil uji chi square didapatkan nilai p 0,006 (p<0,05). Kesimpulan: Senam hamil meminimalisir robekan perineum pada persalinan normal
\end{abstract}

Kata Kunci : senam hamil, persalinan normal, robekan perineum

\begin{abstract}
Background: Perineal tear is the tearing of the pelvic floor muscles. Based on the literature review and previous research, perineal tear often occur in labor, especially in primigravida. Pregnancy exercise is a physical activity that carried out by pregnant women. This study aims to determine the relationship between pregnancy exercise and perineal tear in normal labor at the Pratama Anugrah Clinic in Surabaya. Methods: This study uses an observational analytic method with a retrospective time approach. The number of samples was 34 case groups (perineal tears) and 34 control groups (no perineal tears) in normal delivery using purposive sampling. The instruments used are medical records, written interviews, cameras and checklists. Data analysis used chi square statistical test with a significance level of 0.05. Results: The results showed that there were still many mothers who did not do pregnancy exercise during their pregnancy as many as 43 (63.2\%). Mothers who did not practice pregnancy exercise experienced more perineal tears as much as 27 (79.4\%), while mothers who did practice pregnancy exercise experience
\end{abstract}


perineal tear in normal labor that is $18(53 \%)$. Result of chi square statistical tests obtained $p$ value 0.006 $(p<0.05)$. Conclusion: Pregnancy exercise minimizes perineal tear in normal delivery.

Keywords : pregnancy exercise, normal labor, perineal tear

\section{PENDAHULUAN}

Robekan perineum sering terjadi pada persalinan khususnya primigravida (Anwar, 2011). Penelitian oleh Wulandari terdapat 19 kejadian robekan perineum dari 32 persalinan. Diperkirakan lebih dari $85 \%$ wanita melahirkan pervaginam robekan perineum spontan dan $60-70 \%$ diantaranya membutuhkan penjahitan yang menyebabkan angka morbiditas meningkat. Robekan perineum grade IV atau total akan menimbulkan infeksi dan perdarahan hebat sehingga kematian ibu dapat terjadi (Amin, 2014).

Pemerintah telah menetapkan program kesehatan ibu hamil pada Peraturan Menteri Kesehatan RI Pasal 48 yaitu senam hamil yang dilakukan melalui penyediaan sarana untuk belajar kelompok bagi ibu hamil. Bidan memiliki peran promotif dan preventif dalam hal ini pada UU RI Nomor 4 tahun 2019 dalam pelayanan kesehatan ibu sehingga dapat meminimalisir morbiditas dan mortalitas. Upaya bidan yaitu dengan mengajarkan ibu melakukan senam hamil sebagai persiapan untuk persalinan fisiologis.

Senam hamil merupakan materi ekstra di kelas ibu hamil yang diharapkan dapat dipraktekkan dirumah. Manfaat senam hamil rutin memberikan banyak manfaat sejak ibu hamil sampai ibu bersalin khususnya meningkatkan elastisitas perineum (Pedoman Pelaksanaan Kelas Ibu Hamil, 2009).

Proporsi persalinan usia 10-54 tahun berdasarkan penolong di Indonesia mayoritas di tolong oleh bidan sebanyak 62,7\% (Data Riskesdas, 2018). Penelitian ini dilakukan karena robekan perineum salah satu penyebab morbiditas dan mortalitas, serta dapat meningkatkan elastisitas perineum dan kualitas kehamilan. Berdasarkan fakta - fakta yang tersebut peneliti ingin mengambil penelitian ini.

Tujuan penelitian untuk mengetahui hubungan antara senam hamil dengan robekan perineum pada persalinan normal di Klinik Pratama Anugrah Surabaya. Hipotesis penelitian "Ada hubungan antara senam hamil dengan robekan perineum di Klinik Pratama Anugrah Surabaya". 


\section{METODE}

Jenis penelitian ini yaitu analitik observasional dengan rancangan penelitian studi kasus kontrol dan pendekatan waktu retrospektif. Populasi penelitian ini adalah Ibu postpartum (kunjungan nifas dan kunjungan bayi dan balita) di Klinik Pratama Anugrah Surabaya. Besar sampel dihitung menggunakan rumus purposive sampling didapatkan hasil 68 meliputi 34 kelompok kasus dan 34 kelompok kontrol.

Variabel bebas penelitian ini adalah senam hamil dan variabel terikat adalah robekan perineum. Variabel diukur dengan wawancara tertulis, rekam medis dan checklist yang dibuat oleh peneliti untuk pengumpulan data. Kriteria eksklusi dalam penelitian ini yaitu ibu dengan post seksio sesaria.

Pengumpulan data dilakukan bulan Desember 2019 - April 2020 dimulai dengan penentuan besar sampel yang akan digunakan sesuai populasi. Responden diberikan wawancara tertulis berisi pertanyaan perihal riwayat senam hamil. Kemudian dilakukan konfirmasi data dan status robekan perineum dari rekam medis responden. Pengolahan data dilakukan dengan editing, coding, entry, cleaning dan tabulating. Data yang telah terkumpul akan di analisis menggunakan uji statistik chi square dengan tingkat kemaknaan 0,05. Analisis yang digunakan meliputi analisis univariat untuk deskripsi karakteristik responden dan analisis bivariat untuk menentukan hubungan dua variabel.

\section{Analisis Univariat}

\section{HASIL DAN PEMBAHASAN}

1. Senam Hamil

Pelaksanaan senam hamil masih kurang dilakukan selama kehamilan. Lebih dari setengah jumlah sampel yaitu 43 ibu tidak melakukan senam hamil.

\section{Tabel 1 Pelaksanaan senam hamil}

\begin{tabular}{|c|c|c|c|c|c|c|c|}
\hline \multirow{3}{*}{ NO } & \multirow{3}{*}{ Senam Hamil } & \multicolumn{4}{|c|}{ Robekan Perinum } & \multirow{2}{*}{\multicolumn{2}{|c|}{ TOTAL }} \\
\hline & & \multicolumn{2}{|c|}{$\begin{array}{l}\text { Kasus } \\
\mathrm{n}=34\end{array}$} & \multicolumn{2}{|c|}{$\begin{array}{c}\text { Kontrol } \\
\mathrm{n}=34\end{array}$} & & \\
\hline & & $\mathrm{n}$ & $\%$ & $\mathrm{n}$ & $\%$ & $\mathrm{n}$ & $\%$ \\
\hline 1. & $\mathrm{Ya}$ & 7 & 21 & 18 & 53 & 25 & 37 \\
\hline \multirow[t]{2}{*}{2.} & Tidak & 27 & 79 & 16 & 47 & 43 & 63 \\
\hline & Jumlah & 34 & 100 & 34 & 100 & 68 & 100 \\
\hline
\end{tabular}

2. Robekan Perineum

Persalinan mayoritas terjadi dengan robekan perineum grade II. 
Tabel 2 Grade robekan perineum

\begin{tabular}{lccccccc}
\hline \multirow{2}{*}{ NO } & \multirow{2}{c}{ Krade } & \multicolumn{5}{c}{ Senam Hamil } \\
\cline { 3 - 8 } & & $\mathrm{n}$ & $\%$ & Ya & $\%$ & Tidak & $\%$ \\
\hline 1. & I & 12 & 35 & 7 & 100 & 5 & 19 \\
2. & II & 22 & 65 & 0 & 0 & 22 & 81 \\
3. & III & 0 & 0 & 0 & 0 & 0 & 0 \\
4. & IV & 0 & 0 & 0 & 0 & 0 & 0 \\
& Jumlah & 34 & 100 & 7 & 100 & 27 & 100 \\
\hline
\end{tabular}

Analisis Bivariat

Ibu pada persalinan normal yang tidak melakukan senam hamil berisiko mengalami robekan perineum, sedangkan ibu yang melakukan senam hamil berpeluang memiliki elastisitas perineum.

\section{Tabel 3 Senam hamil dengan robekan perineum}

\begin{tabular}{|c|c|c|c|c|c|c|c|c|}
\hline \multirow{3}{*}{ NO } & \multirow{3}{*}{ Senam Hamil } & \multicolumn{4}{|c|}{ Robekan Perinum } & \multirow{2}{*}{\multicolumn{2}{|c|}{ TOTAL }} & Nilai $p$ \\
\hline & & \multicolumn{2}{|c|}{$\begin{array}{l}\text { Kasus } \\
\mathrm{n}=34\end{array}$} & \multicolumn{2}{|c|}{$\begin{array}{c}\text { Kontrol } \\
\mathrm{n}=34\end{array}$} & & & 0,006 \\
\hline & & $\mathrm{n}$ & $\%$ & $\mathrm{n}$ & $\%$ & $\mathrm{n}$ & $\%$ & \\
\hline 1. & $\mathrm{Ya}$ & 7 & 20,6 & 18 & 53 & 25 & 36,8 & \\
\hline \multirow[t]{2}{*}{2.} & Tidak & 27 & 79,4 & 16 & 47 & 43 & 63,2 & \\
\hline & Jumlah & 34 & 100 & 34 & 100 & 68 & 100 & \\
\hline
\end{tabular}

Tabel 4 menunjukan hasil uji statistik chi square didapatkan nilai $\mathrm{p}=0,006$ yang artinya terdapat hubungan antara senam hamil dengan robekan perineum pada persalinan normal di Klinik Pratama Anugrah Surabaya.

Pelaksanaan senam hamil masih kurang di kalangan ibu hamil. Priyoto, Anisia, Hartono dan Pitayanti berpendapat bahwa salah satu faktor yang dapat mempengaruhi perilaku kesehatan individu yaitu internal locus of control. Kurangnya internal locus of control menyebabkan kurangnya kesadaran seseorang akan dampak kesehatan dari apa yang telah dilakukan. Hal tersebut didukung penelitian oleh Masrurin, Subiyatun dan Rahmawati bahwa dari 110 ibu hamil yang memeriksakan kehamilannya hanya 41 ibu hamil yang mengikuti senam hamil (Priyoto, 2012; Masrurin, 2013).

Perineum adalah ruangan berbentuk jajar genjang di bawah dasar panggul ibu yang dibentuk oleh diafragma pelvis yang berfungsi menyokong vulva dan vagina. Pada persalinan mudah robek otomatis kecuali perineum elastis (Hakimi, 2010; Bartini, 2012).

Seseorang yang melakukan aktifitas fisik akan mengalami pembukaan kapiler otot dan mengurangi difusi oksigen dan zat makanan ke serabut - serabut otot yang sedang berkontraksi. Pengaruh kimiawi yang bekerja pada otot saat aktifitas fisik menyebabkan dilatasi pembuluh darah sehingga peningkatan alirah darah ke otot menjadi lebih besar. Hormon relaxin yang diproduksi banyak selama kehamilan bertugas memberi pelumas 
pada sendi dan jaringan penghubung serta otot di dalam tubuh khususnya perineum (Wiarto, 2013; Aprillia, 2019).

Senam hamil yang dilakukan teratur memiliki manfaat diantaranya membimbing wanita menuju persalinan fisiologis; memperkuat dan mempertahankan elastisitas dan relaksasi otot - otot dinding perut dengan tujuan mempersiapkan rahim kembali pada posisi semula saat postpartum, otot - otot dasar panggul yang berperan dalam persalinan; melonggarkan persendian - persendian yang berhubungan dengan proses persalinan; membentuk sikap tubuh yang prima, sehingga dapat membantu mengatasi keluhan keluhan, letak janin, mengurangi sesak nafas melalui peningkatan kapasitas dan elastisitas paru - paru; memperoleh cara melakukan kontraksi dan relaksasi yang sempurna; menguasai teknik - teknik pernapasan dalam persalinan (Mochtar, 2002; Rahayu, 2018; Aprillia, 2019).

Hasil uji statistic chi square menunjukan adanya hubungan antara senam hamil dengan robekan perineum. Hal ini sesuai dengan penelitian Sari (2017), Rahayu (2018) dan Rifai (2017) bahwa adanya hubungan antara senam hamil dengan robekan perineum.

Penelitian ini menggunakan pendekatan retrospektif dan salah satu instrumen penelitian yaitu wawancara tertulis dimana hanya mengandalkan daya ingat responden.

\section{KESIMPULAN DAN SARAN}

Dapat disimpulkan bahwa terdapat hubungan antara senam hamil dengan robekan perineum di Klinik Pratama Anugrah Surabaya. Keterbatasan penelitian ini yaitu pendekatan retrospektif yang hanya mengandalkan daya ingat repsponden, sehingga peneliti selanjutnya disaranakn menggunakan metode lain.

\section{DAFTAR PUSTAKA}

Amin. (2014) Buku panduan praktik klinik bagi dokter di fasilitas pelayanan kesehatan primer. Jakarta : Ikatan Dokter Indonesia dan Direktur Jenderal Bina Upaya Kesehatan.

Anwar, M., Baziad A., dan Prabowo, P. (2011) Ilmu kandungan. Ed. 3. Jakarta : PT. Bina Pustaka Sarwono, hlm. 323; 329 - 330.

Aprillia, Y. (2019) Prenatal Gentle Yoga.

Bartini, I. (2012) ANC asuhan kebidanan pada ibu hamil normal. Yogyakarta : Nuha Medika.

Departemen Kesehatan Republik Indonesia. (2009) Pedoman pelaksanaan kelas ibu hamil. Jakarta : Direktorat Jenderal Bina Kesehatan Masyarakat. 
Hakimi, M. (2010) Ilmu kebidanan patologi \& fisiologi persalinan. Yogyakarta : CV. Andi Offset, hlm. 10.

Kementerian Kesehatan Badan Penelitian dan Pengembangan Kesehatan. (2018) Hasil utama riskesdas 2018. Jakarta : Kementrian Kesehatan Republik Indonesia

Masrurin, D., Subiyatun, S., dan Rahmawati, N.I., (2013) Minat Ibu Hamil dalam Mengikuti Senam Hamil di BPRB Bina Sehat Bangunjiwo Kasihan, Bantul. Jurnal Ners dan Kebidanan Indonesia, [online] 1(1), hlm. 12-17. Diperoleh dari : http://www.ejournal.almaata.a c.id/index.php/JNKI/article/view/23 $\quad\left[\begin{array}{ll}10 & \text { April }\end{array}\right.$ 2020].

Mochtar, R. (2002) Sinopsis obstetri : obstetri operatif, obstetri social. Jilid 2. Jakarta :EGC.

Priyoto, Anisia, D., Hartono, A., dan Pitayanti, A. (2012) Perilaku Kesehatan dan Pendidikan Kesehatan. Yogyakarta : Pustaka Panasea, hlm. 53 - 54.

Rahayu, D. T., dan Setiadji, A.E. (2018) The correlation of pregnancy exercise with the incidence of primigravida's perineal rupture at kusuma pertiwi clinic kepung sub district kediri regency. The 2nd Joint International Conferences, [online] 2(2), pp. 83-90. Diperoleh dari : https://pdfs.sema nticscholar.org/d4f2/dc7655eb2b430110eb83cb540e60344ce7ac.pdf [10 Oktober 2019].

Rifai, R.A. (2017) Hubungan senam hamil dengan kejadian robekan perineum pada ibu bersalin di klinik umum pratama bina sehat kasihan bantul. Skripsi. Universitas 'Aisyiyah Yogyakarta.

Sari, D.U. (2015) Hubungan senam hamil dengan kejadian rupture perineum pada persalinan normal di RSU PKU Muhammadiyah Bantul. Skripsi. Universitas 'Aisyiyah Yogyakarta.

Wiarto, G. (2013) Fisiologi dan olahraga. Yogyakarta : Graha ilmu, hlm. 43 - 44.

Wulandari, P., Arifianto, dan Zuhara, I.K. (2016) Faktor - faktor yang berhubungan dengan kejadian ruptur perineum spontan di bpm ny. natalia Kecamatan Genuk Kota Semarang. Skripsi. Stikes Widya Husada Semarang. 